\section{Evaluation of Resistance to Plum Pox Virus of North American and European Apricot Cultivars}

\author{
P. Martínez-Gómez ${ }^{1}$, M. Rubio, and F. Dicenta \\ Departamento de Mejora y Patología Vegetal, Centro de Edafología y Biología \\ Aplicada del Segura-Consejo Superior de Investigaciones Científicas, P.O. \\ Box 4195, E-30080 Murcia (Spain)
}

Additional index words. Prunus armeniaca, sharka, susceptibility, breeding

\begin{abstract}
The resistance to a Dideron isolate of Plum pox virus, which causes sharka disease, of four apricot (Prunus armeniaca L.) cultivars from North America ('Harlayne', 'Henderson', 'Sunglo', and 'Veecot') and a Greek cultivar Lito (a cross of American cultivar Stark Early Orange x Greek cultivar Precoce Tirynthos) was evaluated. 'Stark Early Orange' and 'Canino', previously rated as resistant and susceptible respectively, were included as controls. Resistance, herein, was defined as inability to infect plants by graft-inoculation and negative assays by enzyme-linked immunosorbent assay. Cultivars found to be resistant were: 'Harlayne', 'Henderson', 'Sunglo', 'Lito', and 'Stark Early Orange'. Cultivars Veecot and Canino were susceptible.
\end{abstract}

Sharka, a disease caused by Plum pox virus (PPV), is one of the major limiting factors for apricot production in those areas where the virus occurs. Described for the first time in Bulgaria in 1917, it spread throughout all Europe, North Africa, India, and Chile (Németh, 1994), and more recently to North America (Levy et al., 2000). PPV is characterized by its wide genetic variability, but two major strains exist in Europe, i.e., Dideron (PPV-D) and Marcus (PPV-M) (Candresse et al., 1994). In addition, only PPV-D isolates have been detected in South America (Chile) (Reyes et al., 2001) and North America (United States and Canada) (Damsteegt et al., 2001). Other less common PPV isolates include El Amar (PPV-E) in North Africa and Cherry (PPV-C) in Central Europe (Kölber, 2001).

Apricot cultivars of European origin are generally susceptible to both PPV-D and PPV-M. However, based largely on field observations with PPV-M isolates, some North American cultivars exhibit PPV resistance (Martínez-Gómez et al., 2000). MartínezGómez and Dicenta (2000) using a PPV-D isolate demonstrated resistance in apricot cultivars Stella, Stark Early Orange, Goldrich, Harcot, and NJA2 (all of North American origin), and cultivars Pandora ('Stark Early Orange' x 'Precoce Tirynthos') (Greek origin) and Avilara ('Henderson' $x$ 'Colomer') (French origin).

The objective of this study was to evaluate, in controlled conditions, the degree of resistance to PPV-D among several North American and European apricot cultivars.

Received for publication 21 Dec. 2001. Accepted for publication 12 June 2002. This study was financed by project "Optimisation of the apricot genetic improvement by a joint conventional and molecular approach applied to the main agronomical traits" (FAIR N ${ }^{\circ} 6$ CT 98 4345) of the European Union. We gratefully acknowledge the assistance of Mariano Gambín in experimental work.

${ }^{1}$ To whom reprint requests should be addressed. E-mail address: pmartinez@cebas.csic.es.

\section{Materials and Methods}

Plantmaterials. Apricot cultivars evaluated were 'Henderson' and 'Sunglo' (U.S. origin), 'Harlayne' and 'Veecot' (Canadian origin), and 'Lito' (Greek origin). 'Lito' is a cross between 'Precoce Tirynthos' (a traditional Greek cultivar) and the North American cultivar Stark Early Orange. 'Stark Early Orange' and the Spanish cultivar Canino were included as resistant and susceptible controls, respectively.

$P P V-D$ isolate. RB3.30 was the PPV-D isolate used as inoculum, and was maintained at the Instituto Valenciano de Investigaciones Agrarias (IVIA) collection, Valencia, Spain

Resistance evaluation procedure. Evaluation experiments were done in a greenhouse, following procedures described by MartínezGómez and Dicenta (1999). Scions were propagated onto infected symptomatic GF305 peach trees (one scion per tree). Scion grafted trees were forced into dormancy by subjecting them to $7^{\circ} \mathrm{C}$ and darkness for 2 months. After this cold-dark treatment, trees were moved to an insect-proof greenhouse for 4 months. Four cycles of evaluation were performed over a 2 -year period. The number of plants evaluated depended on scion graft success. During each growth cycle (i.e., 2 months in cold chamber and 4 months in greenhouse) scion shoots were observed for leaf symptoms and rated sity of symptoms) 2 months after budbreak. During the first and fourth growth cycles, an ELISA-DASI test (Cambra et al., 1994) was done analyzing five leaves per sample, and optical densities at $405 \mathrm{~nm}\left(\mathrm{OD}_{405}\right)$ were determined after 60-min substrate incubation.

\section{Results and Discussion}

Test cultivars Harlayne (seven plants evaluated), Sunglo (seven plants), Henderson (seven plants), Lito (10 plants), and Stark Early Orange (four plants) proved to be PPV-D resistant. (Asensio, 1996). zero (no symptoms) to five (maximum inten-
Plants appeared normal during four growth cycles and tested negative by enzyme-linked immunosorbent assay (ELISA). Three of six plants of cultivar Veecot developed PPV symptoms and assayed positive by ELISA. Both plants of 'Canino' were symptomatic and positive by ELISA (Table 1).

'Harlayne' was previously reported as resistant to PPV-M (Karayiannis et al., 1999; Polák et al., 1995) and PPV-D (Fuchs et al., 2001) and a potential source of resistance in apricot breeding programs. Our studies also confirmed this cultivar to be resistant.

'Sunglo' had been described as resistant to PPV-M isolates (Karayiannis et al., 1999), while others have reported 'Sunglo' to be susceptible to PPV-D and PPV-M isolates (Balan and Stoian, 1995). These contradictory reports may reflect differences in methodology used, authenticity of plant material evaluated (Martínez-Gómez et al., 2000), or wide variations that exist among the various PPV isolates (Candresse et al., 1994). Further investigations are necessary to clarify this issue with 'Sunglo'.

The PPV-D resistance in 'Henderson' confirms the results of Audergon et al. (1994). However, this cultivar has been described as susceptible to PPV-M isolates (Balan and Stoian, 1995) which are more aggressive in apricot than PPV-D isolates (Candresse et al., 1994).

'Lito' was described as resistant to PPV-M (Karayiannis et al., 1999; Syrgiannidis and Mainou, 1991) and our results extend the resistance to PPV-D.

'Stark Early Orange' was among the first cultivars to be described as resistant to PPV (Syrgiannidis, 1980), a result confirmed in other evaluation assays using both PPV-D and PPV$M$ isolates, even when grafted onto diseased trees (Dosba et al., 1991; Fuchs et al., 2001; Karayiannis et al., 1999).

With 'Veecot', the susceptibility observed in our study agrees with results obtained using PPV-M isolates by Polák et al. (1995). Nevertheless, the fact that only half of the evaluated plants (truly infected plants) showed symptoms and were positive by ELISA could indicate a certain level of tolerance or resistance to PPV, or a lower PPV multiplication rate in this cultivar. In fact, this cultivar has been described as resistant to PPV-M isolates in other assays (Dosba et al., 1991).

The susceptibility of 'Canino' to PPV in our tests confirm the results of other authors using PPV-M and PPV-D isolates (Karayiannis et al., 1999; Martínez-Gómez and Dicenta, 2000).

During cycle 3 , intensity of symptoms was reduced in 'Canino' in comparison with symptoms in cycles 1 and 2 and absent in 'Veecot' (Table 1). The irregular distribution and low titer of PPV described in Prunus tissues (Albrechova, 1986) and as yet undetermined physiological effects due to plant manipulations may have contributed to variation in symptom development.

In conclusion, our results demonstrate the resistance to PPV-D of the North American apricot cultivars Harlayne, Henderson, Sunglo, and Stark Early Orange, and this resistance 
Table 1. Evaluation of resistance of apricot cultivars to Dideron isolate RB3.30 of Plum pox virus.

\begin{tabular}{|c|c|c|c|c|c|c|c|c|c|c|c|c|c|}
\hline \multirow[b]{3}{*}{ Cultivar } & \multirow[b]{3}{*}{$\begin{array}{c}\text { No. } \\
\text { of } \\
\text { plants } \\
\text { evaluated }\end{array}$} & \multicolumn{4}{|c|}{ Cycle 1} & \multirow{2}{*}{\multicolumn{2}{|c|}{$\frac{\text { Cycle } 2}{\text { Symptoms }}$}} & \multirow{2}{*}{\multicolumn{2}{|c|}{$\begin{array}{l}\text { Cycle } 3 \\
\text { Symptoms }\end{array}$}} & \multicolumn{4}{|c|}{ Cycle 4} \\
\hline & & \multicolumn{2}{|c|}{ Symptoms } & \multicolumn{2}{|c|}{ ELISA $^{z}$} & & & & & \multicolumn{2}{|c|}{ Symptoms } & \multicolumn{2}{|c|}{ ELISA } \\
\hline & & $\begin{array}{c}\text { No. } \\
\text { of } \\
\text { symptomatic } \\
\text { plans }\end{array}$ & $\begin{array}{c}\text { Mean } \\
\text { intensity } \\
\text { of } \\
\text { symptoms }\end{array}$ & $\begin{array}{c}\text { No. } \\
\text { of } \\
\text { positive } \\
\text { plants }\end{array}$ & $\mathrm{OD}_{405}^{\mathrm{x}}$ & $\begin{array}{c}\text { No. } \\
\text { of } \\
\text { symptomatic } \\
\text { plants }\end{array}$ & $\begin{array}{c}\text { Mean } \\
\text { intensity } \\
\text { of } \\
\text { symptoms }\end{array}$ & $\begin{array}{c}\text { No. } \\
\text { of } \\
\text { symptomatic } \\
\text { plants }\end{array}$ & $\begin{array}{c}\text { Mean } \\
\text { intensity } \\
\text { of } \\
\text { symptoms }\end{array}$ & $\begin{array}{c}\text { No. } \\
\text { of } \\
\text { symptomatic } \\
\text { plants }\end{array}$ & $\begin{array}{c}\text { Mean } \\
\text { intensity } \\
\text { of } \\
\text { symptoms }\end{array}$ & $\begin{array}{c}\text { No. } \\
\text { of } \\
\text { positive } \\
\text { plants }\end{array}$ & $\mathrm{OD}_{405}$ \\
\hline Harlayne & 7 & 0 & 0 & 0 & 0.08 & 0 & 0 & 0 & 0 & 0 & 0 & 0 & 0.08 \\
\hline Henderson & 7 & 0 & 0 & 0 & 0.06 & 0 & 0 & 0 & 0 & 0 & 0 & 0 & 0.07 \\
\hline Lito & 10 & 0 & 0 & 0 & 0.09 & 0 & 0 & 0 & 0 & 0 & 0 & 0 & 0.06 \\
\hline Sunglo & 7 & 0 & 0 & 0 & 0.08 & 0 & 0 & 0 & 0 & 0 & 0 & 0 & 0.09 \\
\hline Veecot & 6 & 1 & 2 & 1 & 0.45 & 2 & 1 & 0 & 0 & 3 & 1 & 3 & $0.66^{\mathrm{w}}$ \\
\hline \multicolumn{14}{|l|}{ Stark Early } \\
\hline Orange & 4 & 0 & 0 & 0 & 0.07 & 0 & 0 & 0 & 0 & 0 & 0 & 0 & 0.07 \\
\hline Canino & 2 & 2 & 2 & 1 & 0.40 & 2 & 2 & 2 & 1 & -- & -- & -- & --- \\
\hline
\end{tabular}

${ }^{2}$ Enzyme-linked immunosorbent assay (ELISA).

Intensity: $0=$ no symptoms to $5=$ maximum intensity.

${ }^{\mathrm{x}} \mathrm{OD}_{405}=$ optical density at $405 \mathrm{~nm}$ values after 60 minutes incubation. Note: Mean $\mathrm{OD}_{405}$ values in infected and healthy peach (Prunus persica L.) rootstocks were 2.10 and 0.12 , respectively. Noninoculated apricot controls had $\mathrm{OD}_{405}$ values ranging from 0.10 to 0.14 .

"Mean $\mathrm{OD}_{405}$ value for 'Veecot' plants testing negative by ELISA was 0.07 .

has been incorporated into other cultivars such as 'Lito'. Finally, the level of PPV resistance found, considering that apricot is the species mostaffected by PPV inEurope (Németh, 1994), is an important consideration in limiting virus spread in North America, where only PPV-D has been detected.

\section{Literature Cited}

Albrechtova,L. 1986. Investigations on the distribution of sharka virus (Plum pox) in tissue of Prunus domestica. Z. Pflanz. Pflanz. 93:190-201.

Asensio, M. 1996. El virus de la sharka (Plum pox virus). Caracterización, diagnóstico y detección mediante anticuerpos monoclonales específicos. Univ. of Valencia. Spain. PhD Diss.

Audergon, J.M., F. Dosba, I. Karayiannis, and F. Dicenta. 1994. Amélioration de l'abricotier pour la résistance à la sharka. EPPO Bul. 24: 741-748.

Balan, V. andE. Stoian. 1995. Susceptibility of certain apricot-tree to the plum pox virus pathogenic action. Acta Hort. 384:565-569.

Cambra, M., M. Asensio, M.T. Gorris, J.A. García, J.J. Moya, D. López-Abella, C. Vela, and A. Sanz. 1994. Detection of Plum pox potyvirus using monoclonal antibodies to structural and non- structural proteins. EPPO Bul. 24:569-578.

Candresse, T., G. MacQuaire, M. Lanneau, M. Bousalem, T. Wetzel, L. Quiot-Douine, J.B. Quiot, and J. Dunez. 1994. Detection of Plum pox potyvirus and analysis of its molecular variability using immunocapture-PCR. EPPO Bul. 24:585-595.

Damsteegt, V.S., A.L. Stone, D.G. Luster, F.E. Gildow, L. Levy, and R. Welliver. 2001. Preliminary characterization of a North American isolate of Plum pox virus from naturally infected peach and plum orchards in Pennsylvania, USA. Acta Hort. 550:145-151.

Dosba, F., F. Denise, P. Maison, G. Massonie, and J.M. Audergon. 1991. Plum pox virus resistance of apricot. Acta Hort. 293:569-579.

Fuchs E., M. Grüntzig, I. Ernst, and H. Kegler. 2001. Comparison of apricot genotypes with different resistance level to Plum pox virus (PPV). Acta Hort. 550:103-106.

Karayiannis, I., B. Di Terlizzi, and J.M. Audergon. 1999. Susceptibility of apricot cvs. to plum pox virus disease. Acta Hort. 488:753-759.

Kölber, M. 2001. Workshop on Plum pox. Acta Hort. 550:249-255.

Levy, L., V.S. Damsteegt, and R. Welliver. 2000. First report of Plum pox virus (sharka disease) in Prunus persica in the United States. Plant Dis. 84:202.
Martínez-Gómez,P. and F. Dicenta. 1999. Evaluation of resistance to sharka in the breeding apricot program in CEBAS-CSIC in Murcia (Spain). Acta Hort. 488:731-737.

Martínez-Gómez, P. and F. Dicenta. 2000. Evaluation of resistance of apricot cultivars to a Spanish isolate of Plum pox potyvirus (PPV). Plant Breed. 119:179-181.

Martínez-Gómez,P., F. Dicenta, and J.M. Audergon. 2000. Behaviour of apricot (Prunus armeniaca L.) cultivars in the presence of sharka (Plum pox potyvirus): A review. Agronomie 20:407-422 .

Németh, M. 1994. History and importance of plum pox in stone-fruit production. EPPO Bul. 24: 525-537.

Polák, J., P. Kominek, M. Jokes, I. Oukropec, and B. Krska. 1995. The evaluation of resistance of apricots to Plum pox virus by ELISA and ISEM. Acta Hort. 386:285-289.

Reyes, F., M.A. Reyes, P. Sepúlveda, J.J. LópezMoya, and H. Prieto. 2001. New insights of Plum pox virus in Chile. Acta Hort. 550:135-140.

Syrgiannidis, G. 1980. Selection of two apricot varieties resistant to sharka virus. Acta Phytopath. Scient. Hungaricae 15:85-87.

Syrgiannidis, G. and A. Mainou. 1991. Two new apricot varieties resistant to sharka (Plum Pox) disease created by crossing. Deuxièmes rencontres sur l'abricotier. Avignon, May 1991:136. 